\title{
PENGARUH FAKTOR PENENTU PERILAKU IBU DALAM PEMBERIAN IMUNISASI DASAR PADA BAYI DI WILAYAH KERJA PUSKESMAS KOSIK PUTIH KABUPATEN PADANG LAWAS UTARA TAHUN 2019
}

\author{
Fera Natalia Sembiring, Tarsyad Nugraha, Linda Hernike Napitupulu \\ Program Pasca Sarjana Institut Kesehatan Helvetia Medan \\ E-mail : ferabiring@gmail.com
}

\begin{abstract}
Immunization has proven to be one of the most important public health efforts. The report of the Kosik Putih Health Center in North Padang Lawas Regency in 2016 recorded a complete basic immunization achievement of 52 babies $(63.9 \%)$ from the baby target of 76 babies and in 2017 amounted to 59 babies (73.8\%) from the baby target of 80 babies. The purpose of this study was to study the determinants that influence mothers in giving immunizations to infants in the working area of the Kosik Putih Health Center in Padang Lawas Utara Regency in 2019. Study design used an analytical survey with a cross sectional study approach. The population in this study were all mothers who brought their babies for basic immunization in the working area of Kosik Putih Community Health Center in North Padang Lawas Regency in 2019 totaling 59 mothers. The sampling technique uses the entire population as samples (total sampling). Data analysis used univariate, bivariate and multivariate analysis with logistic regression. The results of this study indicate the sig value on the knowledge variable $(\mathrm{p}=0.003)$, attitudes $(\mathrm{p}=0.018)$, socio-cultural $(\mathrm{p}=0.271)$, availability of health facilities $(\mathrm{p}=0.376)$, affordability of health facilities $(0.472)$, personnel support health $(\mathrm{p}=0.030)$ and husband's support $(\mathrm{p}=0.725)$. The variable with the greatest Exp (B) value is knowledge $(39,565)$. The variables that influence behavior in providing basic immunization to infants in the working area of Kosik Putih Community Health Center, North Padang Lawas Regency in 2019 are knowledge, attitudes and support of health workers and the most influential variable is knowledge.
\end{abstract}

Keywords : Determinants, Mother Behavior, Basic Immunization

\begin{abstract}
Abstrak
Imunisasi telah terbukti sebagai salah satu upaya kesehatan masyarakat yang sangat penting . Laporan Puskesmas Kosik Putih Kabupaten Padang Lawas Utara tahun 2016 tercatat capaian imunisasi dasar lengkap sebesar 52 bayi $(63,9 \%)$ dari sasaran bayi sebesar 76 bayi dan tahun 2017 sebesar 59 bayi $(73,8 \%)$ dari sasaran bayi sebesar 80 bayi. Tujuan dari penelitian ini untuk mengetahui faktor penentu yang memengaruhi perilaku ibu dalam pemberian imunisasi dasar pada bayi di wilayah kerja Puskesmas Kosik Putih Kabupaten Padang Lawas Utara tahun 2019. Jenis penelitian menggunakan survei analitik dengan pendekatan cross sectional study. Populasi dalam penelitian ini adalah seluruh ibu yang membawa bayinya untuk imunisasi dasar yang ada di wilayah kerja Puskesmas Kosik Putih Kabupaten Padang Lawas Utara tahun 2019 berjumlah 59 ibu. Teknik pengambilan sampel menggunakan seluruh populasi menjadi sampel (total sampling).. Analisis data menggunakan analisis univariat, bivariat dan multivariat dengan regresi logistik. Hasil penelitian ini menunjukkan nilai sig pada variable pengetahuan $(p=0,003)$, sikap $(p=0,018)$, sosial budaya $(\mathrm{p}=0,271)$, ketersediaan fasilitas kesehatan $(\mathrm{p}=0,376)$, keterjangkauan fasilitas kesehatan $(0,472)$, dukungan tenaga kesehatan $(\mathrm{p}=0,030)$ dan dukungan suami $(\mathrm{p}=0,725)$. Variabel dengan nilai $\operatorname{Exp}(\mathrm{B})$ terbesar adalah pengetahuan $(39,565)$. Variable yang mempengaruhi perilaku dalam pemberian imunisasi dasar pada bayi di wilayah kerja Puskesmas Kosik Putih Kabupaten Padang Lawas Utara tahun 2019 adalah pengetahuan, sikap dan dukungan tenaga kesehatan dan variabel yang paling berpengaruh adalah pengetahuan.
\end{abstract}

Kata Kunci : Faktor Penentu, Perilaku Ibu, Imunisasi Dasar 


\section{PENDAHULUAN}

Tercapainya kemampuan sehat bagi setiap penduduk agar dapat mewujudkan derajat kesehatan masyarakat yang optimal sebagai salah satu tujuan untuk kebijaksanaan umum dari tujuan nasional merupakan tujuan pembangunan keseahtan. Agar tujuan pembangunan bidang kesehatan tersebut dapat terwujud, diperlukan suatu tatanan yang mencerminkan upaya bangsa Indonesia dalam meningkatkan derajat kesehatan yang optimal dan sebagai perwujudan upaya tersebut dibentuk sistem kesehatan nasional. Penyakit menular masih merupakan masalah, sementara penyakit degeneratif juga muncul sebagai masalah. Imunisasi merupakan program pemerintah yang sangat penting karena program imunisasi telah menujukkan keberhasilan yang luar biasa dan merupakan usaha yang sangat hemat biaya dalam mencegah penyakit menular. Imunisasi telah terbukti sebagai salah satu upaya kesehatan masyarakat yang sangat penting. Vaksinasi terhadap 7 penyakit telah direkomendasikan EPI sebagai imunisasi rutin di negara berkembang: BCG, DPT, Polio, Campak dan Hepatitis B (IDAI, 2014).

Menurut World Health Organization (WHO) (2016), ada 21,8 juta anak pada tahun 2013 tidak mendapatkan imunisasi. Pelaksanaan imunisasi dapat mencegah 2-3 juta kematian setiap tahun akibat penyakit difteri, tetanus, pertusis, dan campak pada tahun 2014, namun pada tahun 2014 terdapat 18,7 juta bayi diseluruh dunia tidak mendapat imunisasi rutin DPT3, yang lebih dari $60 \%$ dari anak-anak ini tinggal di 10 negara yaitu Republik Demokrasi Kongo, Eutopia, India, Indonesia, Iraq, Nigeria, Pakistan, Philipina, Uganda, dan Afrika Selatan.

Menurut statistik kesehatan dunia 2015, cakupan imunisasi secara global untuk imunisasi DPT3 sebesar 84\%, HepB3 sebesar $81 \%$ dan campak sebesar $84 \%$ pada tahun 2013, belum mencapai target imunisasi global yaitu sebesar 90\% dari jumlah anak usia 0-11 bulan di dunia. Indonesia termasuk negara yang tidak mencapai target tersebut, dengan cakupan imunisasi DPT3 sebesar 85\%, HepB3 sebesar $85 \%$ dan campak sebesar $84 \%$ pada tahun 2013. Oleh karena itu, dari 194 negara anggota WHO, 65 negara diantaranya memiliki cakupan imunisasi DPT3 dibawah target global 90\%, termasuk Indonesia Persentase imunisasi menurut jenisnya berdasarkan data dari Profil Kesehatan Indonesia tahun 2016 yang tertinggi sampai terendah adalah untuk DPTHB1 (94,7\%), DPTHB3 (93,0\%), BCG (92,7\%), Polio $(92,2 \%)$ dan terendah Campak $(92,5)$. Bila dilihat masing-masing imunisasi menurut provinsi, Provinsi Aceh menempati urutan ke 32 dari 34 provinsi dengan hasil BCG $(73,8 \%), \quad \mathrm{HB}<7$ hari $(77,2 \%), \quad$ DPTHB1 $(70,2 \%)$, DPTHB3, 68,1\%), Polio $(71,7 \%)$ dan Campak (73,5\%) (Kemenkes RI, 2016).

Indonesia masih menempati peringkat ke-4 di dunia setelah India, Nigeria, dan Republik Demokrasi Kongo untuk undervaccination children dalam cakupan imunisasi DPT3. Hal ini mengakibatkan Indonesia menjadi salah satu negara prioritas yang diidentifikasi oleh WHO dan UNICEF untuk melaksanakan akselerasi dalam pencapaian target $100 \%$ UCI Desa/ Kelurahan. Diperkirakan 1,5 juta balita di Indonesia belum terjangkau program imunisasi dasar maupun pemberian vaksin lainnya (WHO, 2014).

Pencapaian desa dengan UCI di Provinsi Sumatera Utara tahun 2016 hanya $75,5 \%$. Kabupaten/kota yang desanya telah mencapai UCI $100 \%$ yaitu kota Medan dan Pakphak Barat. Pencapaian UCI lebih $80 \%$ tetapi tidak mencapai $100 \%$ sebanyak 19 kabupaten/kota, sedangkan cakupan UCI dibawah $50 \%$ yakni Nias Selatan $(8,7 \%)$, Padang Lawas (36,3\%), Pematang Siantar $(45,3 \%)$ dan Padang Sidimpuan $(19,0 \%)$ (Dinkes Provsu, 2016).

Angka Kematian Bayi (AKB) di Indonesia masih tinggi, $80 \%$ diakibatkan oleh Pneumonia. Hal tersebut juga ditegaskan oleh Strategic Advisory Group of Experts (SAGE) kelompok penasehat utama WHO untuk vaksinasi dan imunisasi didunia dalam pertemuan di Swiss, Pneumokokus merupakan penyebab utama morbititas dan mortalitas didunia dan vaksinasi merupakan 
upaya terbaik untuk mencegah penyakit Pneumokokus (Lisnawati, 2011).

Pada kondisi ini, diharapkan sistem kekebalan tubuh dapat bekerja secara optimal. Namun demikian, pada kondisi tertentu beberapa bayi tidak mendapatkan imunisasi dasar secara lengkap. Kelompok inilah yang disebut dengan drop out (DO) imunisasi. Bayi yang mendapatkan imunisasi DPT/HB1 pada awal pemberian imunisasi, namun tidak mendapatkan imunisasi campak, disebut Drop Out Rate DPT/HB1-Campak. Indikator ini diperoleh dengan menghitung selisih penurunan cakupan imunisasi campak terhadap cakupan imunisasi DPT/HB1.

Keberhasilan seorang bayi dalam mendapatkan imunisasi dasar diukur melalui indikator imunisasi dasar lengkap. Cakupan imunisasi dasar lengkap pada bayi di Indonesia pada tahun 2015 yaitu mencapai 86,5\% dimana cakupan tertinggi berada di Provinsi Jambi $(99,8 \%)$ dan terendah yaitu Provinsi Papua (47,2\%) (Kemenkes RI, 2015).

Dari Persentase Imunisasi dasar lengkap di Indonesia tahun 2016 yang menduduki tingkat yang paling tinggi di Bali sekitar 62,3\%, DKI Jakarta sekitar 61,2\%, Bangka Belitung sekitar $60,0 \%$, yang paling rendah di Papua sekitar 20,3\%, Papua Barat sekitar 18,3\%, Maluku Utara sekitar 17,7\% (Kemenkes RI, 2016).

Berdasarkan data dari Dinas Kesehatan Provinsi Sumatera Utara tahun 2016, angka cakupan Imunisasi Dasar Lengkap (IDL) di Sumatera Utara belum mencapai target yaitu sebesar $85,31 \%$, namun sedikit lebih mengalami peningkatan dibandingkan tahun 2015 yaitu sebesar $79,9 \%$. Kabupaten/kota yang desanya telah mencapai IDL di atas $90 \%$ yaitu Nias $(91,60 \%)$, Toba Samosir $(91,15 \%)$, Asahan (96,96\%), Simalingun $(96,58 \%)$, Dairi $(90,78 \%)$, Deli Serdang $(90,81 \%)$, Langkat (91,95\%), Labuhan Batu Utara (108,89\%) dan Kota Medan (101,83\%) (Dinkes Provsu, 2016)

Data yang diperoleh dari Dinas Kabupaten Padang Lawas Utara tercatat bahwa capaian imunisasi dasar lengkap meningkat setiap tahun. Tahun 2017 tercatat capaian imunisasi dasar lengkap sebanyak 5.673 bayi $(73,8 \%)$, mengalami kenaikan dibandingkan tahun 2016 sebesar 3.688 bayi $(71,34 \%)$ dan tahun 2015 sebesar 3.343 bayi (64,68\%) (Dinkes Kab.Padang Lawas, 2017).

Berdasarkan Laporan Puskesmas

Kosik Putih Kabupaten Padang Lawas Utara tahun 2015 tercatat capaian imunisasi dasar lengkap di wilayah kerja Puskesmas Kosik sebesar 42 bayi $(56,0 \%)$ dari sasaran sebesar 75 bayi, terjadi peningkatan dibandingkan tahun 2016 sebesar 52 bayi $(63,9 \%)$ dari sasaran bayi sebesar 76 bayi dan tahun 2017 sebesar 59 bayi $(73,8 \%)$ dari sasaran bayi sebesar 80 bayi.

\section{METODE PENELITIAN}

Penelitian ini merupakan suatu penelitian survei analitik dengan desain cross secsional study, yang bertujuan untuk mengetahui pengaruh faktor predisposing, enabling dan reinforcing terhadap perilaku ibu dalam pemberian imunisasi dasar pada bayi di wilayah kerja Puskesmas Kosik Putih Kabupaten Padang Lawas Utara.tahun 2019. Populasi dalam penelitian ini adalah seluruh ibu yang membawa bayinya untuk imunisasi dasar yang ada di wilayah kerja Puskesmas Kosik Putih Kabupaten Padang Lawas Utara tahun 2019 berjumlah 59 ibu. Pengambilan sampel menggunakan seluruh populasi menjadi sampel (total sampling). Analisis data yang digunakan dalam penelitian ini adalah analisis univariat, bivariat dan multivariat dengan regresi logistik.

\section{HASIL PENELITIAN Karakteristik Responden:}

Hasil pengumpulan data tentang karakteristik bahwa umur $<30$ tahun sebanyak 43 orang $(72,9 \%)$ dan umur $\geq 30$ tahun sebanyak 16 orang $(27,1 \%)$. Responden berdasarkan tingkat pendidikan, pendidikan rendah sebanyak 30 orang $(50,8 \%)$ dan pendidikan tinggi sebanyak 29 orang $(49,2)$. Berdasarkan jenis pekerjaan, responden yang bekerja sebanyak 29 orang $(49,2 \%)$ dan yang tidak bekerja sebanyak 30 orang $(50,8)$. 
Tabel 1. Distribusi Frekuensi Karakteristik Responden di Wilayah Kerja Puskesmas Kosik Putih Kabupaten Padang Lawas Utara Tahun 2019

\begin{tabular}{llcc}
\hline No. & \multicolumn{1}{c}{ Karakteristik } & Frekuensi (f) & \% \\
\hline & Kelompok Umur (Tahun) & & \\
1. & $<30$ tahun & 43 & 72,9 \\
2. & $\geq 30$ tahun & 16 & 27,1 \\
\hline$\quad$ Total & 59 & 100,0 \\
\hline & Jenis Pendidikan & & \\
1. & Rendah (SD - SMP) & 30 & 50,8 \\
2. & Tinggi (SMA - Perguruan TInggi) & 29 & 49,2 \\
\hline$\quad$ Total & 59 & 100,0 \\
\hline & Pekerjaan & & \\
1. & Bekerja & 29 & 49,2 \\
2. & Tidak Bekerja & 30 & 50,8 \\
\hline & Total & 59 & 100,0 \\
\hline
\end{tabular}

\section{Analisis Univariat}

Hasil pengukuran pengetahuan menunjukkan dari 59 responden mayoritas memiliki pengetahuan dengan kategori baik sebanyak 36 orang $(61,0 \%)$ dan dengan kategori kurang sebanyak 23 orang $(39,0 \%)$. Hasil pengukuran sikap menunjukkan bahwa dari 59 responden mayoritas memiliki sikap dengan kategori positif sebanyak 33 orang $(55,9 \%)$ dan dengan kategori negatif sebanyak 26 orang $(44,1 \%)$. Hasil pengukuran sosial budaya menunjukkan bahwa dari 59 responden mayoritas memiliki sosial budaya dengan kategori baik sebanyak 38 orang $(64,4 \%)$ dan dengan kategori kurang yaitu sebanyak 21 orang $(35,6 \%)$. Hasil pengukuran ketersediaan fasilitas kesehatan menunjukkan bahwa dari 59 responden mayoritas mengatakan ketersediaan fasilitas kesehatan dengan kategori baik sebanyak 34 orang $(57,6 \%)$ dan dengan kategori kurang sebanyak
25 orang $(42,4 \%)$. Hasil pengukuran dukungan tenaga kesehatan menunjukkan bahwa dari 59 responden mayoritas mendapat dukungan tenaga kesehatan dengan kategori mendukung sebanyak 30 orang $(50,8 \%)$ dan dengan kategori tidak mendukung yaitu sebanyak 29 orang $(49,2 \%)$.

Hasil pengukuran dukungan suami/keluarga menunjukkan bahwa dari 59 responden mayoritas mendapat dukungan suami/ keluarga dengan kategori mendukung sebanyak 30 orang $(50,8 \%)$ dan dengan kategori tidak mendukung yaitu sebanyak 29 orang $(49,2 \%)$. Hasil pengukuran perilaku ibu dalam pemberian imunisasi dasar menunjukkan bahwa dari 59 responden mayoritas melaksanakan pemberian imunisasi dasar dengan kategori baik sebanyak 20 orang $(33,9 \%)$ dan dengan kategori kurang sebanyak 20 orang $(33,9 \%)$.

Tabel 2. Distribusi Frekuensi Kategori Pengetahuan, Sikap, Sosial Budaya, Ketersediaan Fasilitas Kesehatan, Dukungan Tenaga Kesehatan, Dukungan Suami/Keluarga dan Perilaku Dalam Pemberian Imunisasi Dasar i Wilayah Kerja Puskesmas Kosik Puth Kabupaten Padang Lawas Utara Tahun 2019

\begin{tabular}{lll}
\hline Variabel & f & \% \\
\hline Pengetahuan & & \\
Kurang & 23 & 39,0 \\
Baik & 36 & 61,0 \\
\hline Sikap & & \\
Negatif & 26 & 44,1 \\
Positif & 33 & 55,9 \\
\hline Sosial Budaya & & \\
Kurang & 21 & 35,6
\end{tabular}




\begin{tabular}{lcc} 
Baik & 38 & 64,4 \\
\hline Ketersediaan Fasilitas Kesehatan & & \\
Kurang & 25 & 42,4 \\
Baik & 34 & 57,6 \\
\hline Dukungan Keterjangkauan Fasilitas Kesehatan & \\
Tidak terjangkau & 19 & 32,2 \\
Terjangkau & 40 & 67,8 \\
\hline Dukungan Tenaga Kesehatan & & \\
Tidak Mendukung & 29 & 49,2 \\
Mendukung & 30 & 50,8 \\
\hline Dukungan Suami/Keluarga & & 49,2 \\
Tidak mendukung & 29 & 50,8 \\
Mendukung & 30 & 33,9 \\
\hline Perilaku Ibu & & 66,1 \\
Kurang & 20 & \\
Baik & 39 & \\
\hline
\end{tabular}

\section{Analisis Bivariat}

Berdasarkan hasil penelitian, diketahui 59 jumlah responden didapatkan bahwa dari 43 ibu yang berumur $<30$ tahun yang memiliki perilaku dalam kategori kurang sebanyak $34,9 \%$, sedangkan dari 16 ibu yang beumur > 30 tahun yang memiliki perilaku kurang sebanyak 31,3\%. Hasil uji statistik chi-square diperoleh nilai $p=0,525>0,05$. Hal ini berarti tidak ada hubungan antara umur dengan perilaku ibu dalam pemberian imunisasi dasar.

Berdasarkan hasil penelitian dari 59 jumlah responden didapatkan bahwa dari $30 \mathrm{ibu}$ berpendidikan rendah yang memiliki perilaku dalam kategori kurang sebanyak 40,0\%, sedangkan dari 29 ibu berpendidikan tinggi yang memiliki perilaku kurang sebanyak 27,6\%. Hasil uji statistik chi-square diperoleh nilai $p=0,232>0,05$. Hal ini berarti tidak ada hubungan antara pendidikan dengan perilaku ibu dalam pemberian imunisasi dasar.

Berdasarkan hasil penelitian diketahui dari 59 jumlah responden didapatkan bahwa dari 29 ibu bekerja yang memiliki perilaku dalam kategori kurang sebanyak 27,6\%, sedangkan dari 30 ibu tidak bekerja yang memiliki perilaku kurang sebanyak 40,0\%. Hasil uji statistik chi-square diperoleh nilai $p=$ $0,232>0,05$. Hal ini berarti tidak ada hubungan antara pekerjaan dengan perilaku ibu dalam pemberian imunisasi dasar.

Berdasarkan hasil penelitian dari 59 jumlah responden didapatkan bahwa dari $23 \mathrm{ibu}$ yang memiliki pengetahuan kurang yang memiliki perilaku dalam kategori kurang sebanyak $73,9 \%$, sedangkan dari 36 ibu yang memiliki pengetahuan baik yang memiliki perilaku kurang sebanyak 8,3\%. Hasil uji statistik chi-square diperoleh nilai $p=0,000<$ 0,05 . Hal ini berarti ada hubungan antara pengetahuan dengan perilaku ibu dalam pemberian imunisasi dasar.

Berdasarkan hasil penelitian diketahui dari 59 jumlah responden didapatkan bahwa dari 26 ibu yang memiliki sikap negatif yang memiliki perilaku dalam kategori kurang sebanyak 69,2\%, sedangkan dari 33 ibu yang memiliki sikap positif yang memiliki perilaku kurang sebanyak $6,1 \%$. Hasil uji statistik chisquare diperoleh nilai $p=0,000<0,05$. Hal ini berarti ada hubungan antara sikap dengan perilaku ibu dalam pemberian imunisasi dasar.

Berdasarkan hasil penelitian diketahui dari 59 jumlah responden didapatkan bahwa dari 21 ibu yang memiliki social budaya kurang yang memiliki perilaku dalam kategori kurang sebanyak $57,1 \%$, sedangkan dari 38 ibu yang memiliki sosial budaya baik yang memiliki perilaku kurang sebanyak 21,1\%. Hasil uji statistik chi-square diperoleh nilai $p=0,006<$ 0,05 . Hal ini berarti ada hubungan antara sosial budaya dengan perilaku ibu dalam pemberian imunisasi dasar.

Berdasarkan hasil penelitian diketahui dari 59 jumlah responden didapatkan bahwa dari 25 ibu yang menyatakan ketersediaan 
fasilitas keseahtan kurang yang memiliki perilaku dalam kategori kurang sebanyak $48,0 \%$, sedangkan dari 34 ibu yang menyatakan ketersediaan fasilitas kesehatan baik yang memiliki perilaku kurang sebanyak $23,5 \%$. Hasil uji statistik chi-square diperoleh nilai $p=$ $0,046<0,05$. Hal ini berarti ada hubungan antara ketersediaan fasilitas kesehatan dengan perilaku ibu dalam pemberian imunisasi dasar.

Berdasarkan hasil pemnelitian diketahui dari 59 jumlah responden didapatkan bahwa dari 19 ibu yang menyatakan keterjangkauan fasilitas kesehatan tidak terjangkau yang memiliki perilaku dalam kategori kurang sebanyak 52,6\%, sedangkan dari 40 ibu yang menyatakan keterjangkauan fasilitas kesehatan terjangkau yang memiliki perilaku kurang sebanyak 25,0\%. Hasil uji statistik chi-square diperoleh nilai $p=0,037<$ 0,05 . Hal ini berarti ada hubungan antara keterjangkauan fasilitas kesehatan dengan perilaku ibu dalam pemberian imunisasi dasar.

Berdasarkan hasil penelitan diketahui dari 59 jumlah responden didapatkan bahwa dari 29 ibu yang menyatakan dukungan tenaga kesehatan kategori tidak mendukung yang memiliki perilaku dalam kategori kurang sebanyak $58,6 \%$, sedangkan dari $30 \mathrm{ibu}$ yang menyatakan dukungan tenaga kesehatan kategori mendukung yang memiliki perilaku kurang sebanyak $10,0 \%$. Hasil uji statistik chisquare diperoleh nilai $p=0,000<0,05$. Hal ini berarti ada hubungan antara dukungan tenaga kesehatan dengan perilaku ibu dalam pemberian imunisasi dasar.

Berdasarkan hasil penelitan diketahui dari 59 jumlah responden didapatkan bahwa dari 29 ibu yang menyatakan dukungan suami/ keluarga kategori tidak mendukung yang memiliki perilaku dalam kategori kurang sebanyak 48,3\%, sedangkan dari 30 ibu yang menyatakan dukungan suami/ keluarga kategori mendukung yang memiliki perilaku kurang sebanyak 20,0\%. Hasil uji statistik chi-square diperoleh nilai $p=0,021<0,05$. Hal ini berarti ada hubungan antara dukungan suami/ keluarga dengan perilaku ibu dalam pemberian imunisasi dasar.

Tabel 3. Tabulasi Silang Hubungan Pengetahuan, Sikap, Sosial Budaya, Dukungan Keluarga dan Dukungan Tenaga Kesehatan dengan Perilaku Donor Darah di Unit Transfusi Darah RS Dr. Fauziah Bireuen Tahun 2019

\begin{tabular}{|c|c|c|c|c|c|c|c|}
\hline \multirow{3}{*}{ Variabel } & \multicolumn{4}{|c|}{$\begin{array}{c}\text { Perilaku Ibu dalam Pemberian } \\
\text { Imunisasi Dasar }\end{array}$} & \multirow{2}{*}{\multicolumn{2}{|c|}{ Total }} & \multirow{3}{*}{ p-value } \\
\hline & \multicolumn{2}{|c|}{ Kurang } & \multicolumn{2}{|c|}{ Baik } & & & \\
\hline & $\mathbf{f}$ & $\%$ & $\mathbf{f}$ & $\%$ & $\mathbf{f}$ & $\%$ & \\
\hline \multicolumn{8}{|l|}{ Umur } \\
\hline$<30$ tahun & 15 & 34,9 & 28 & 65,1 & 43 & 100,0 & 0,525 \\
\hline$>30$ tahun & 5 & 31,3 & 11 & 68,8 & 16 & 100,0 & \\
\hline \multicolumn{8}{|l|}{ Pendidikan } \\
\hline Rendah & 12 & 40,0 & 18 & 60,0 & 30 & 100,0 & 0,232 \\
\hline Tinggi & 8 & 27,6 & 21 & 72,4 & 29 & 100,0 & \\
\hline \multicolumn{8}{|l|}{ Pekerjaan } \\
\hline Bekerja & 8 & 27,6 & 21 & 72,4 & 29 & 100,0 & 320,2 \\
\hline Tidak bekerja & 12 & 40,0 & 18 & 60,0 & 30 & 100,0 & \\
\hline \multicolumn{8}{|l|}{ Pengetahuan } \\
\hline Kurang & 17 & 73,9 & 6 & 26,1 & 23 & 100,0 & 0,000 \\
\hline Baik & 3 & 8,3 & 33 & 91,7 & 36 & 100,0 & \\
\hline \multicolumn{8}{|l|}{ Sikap } \\
\hline Negatif & 18 & 69,2 & 8 & 30,8 & 26 & 100,0 & 0,000 \\
\hline Positif & 2 & 6,1 & 31 & 93,9 & 33 & 100,0 & \\
\hline \multicolumn{8}{|l|}{ Sosial Budaya } \\
\hline Kurang & 12 & 57,1 & 9 & 42,9 & 21 & 100,0 & 0006 \\
\hline Baik & 8 & 21,1 & 30 & 78,9 & 38 & 100,0 & 0,006 \\
\hline
\end{tabular}




\begin{tabular}{|c|c|c|c|c|c|c|c|}
\hline \multicolumn{8}{|c|}{$\begin{array}{l}\text { Ketersediaan Fasilitas } \\
\text { Kesehatan }\end{array}$} \\
\hline Kurang & 12 & 48,0 & 13 & 52,0 & 25 & 100,0 & \multirow[t]{2}{*}{0,046} \\
\hline Baik & 8 & 23,5 & 26 & 76,5 & 34 & 100,0 & \\
\hline \multicolumn{8}{|c|}{ Keterjangkaan Fasilitas } \\
\hline Kesehatan & & & & & & & \multirow{3}{*}{0,037} \\
\hline Tidak terjangkau & 10 & 52,6 & 9 & 47,4 & 19 & 100,0 & \\
\hline Terjangkau & 10 & 25,0 & 30 & 75,0 & 40 & 100,0 & \\
\hline \multicolumn{8}{|c|}{ Dukungan Tenaga Kesehatan } \\
\hline Tidak mendukung & 17 & 58,6 & 12 & 41,4 & 29 & 100,0 & \multirow[t]{2}{*}{0,000} \\
\hline Mendukung & 3 & 10,0 & 27 & 90,0 & 30 & 100,0 & \\
\hline \multicolumn{8}{|c|}{ Dukungan Suami/ Keluarga } \\
\hline Tidak mendukung & 14 & 48,3 & 15 & 51,7 & 29 & 100,0 & \multirow[t]{2}{*}{0,021} \\
\hline Mendukung & 6 & 20,0 & 24 & 80,0 & 30 & 100,0 & \\
\hline
\end{tabular}

\section{Analisis Multivariat}

Berdasarkan hasil di atas diketahui bahwa terdapat 3 variabel bebas yang signifikan berpengaruh terhadap terhadap perilaku ibu dalam pemberian imunisasi dasar karena masing-masing variabel tersebut memiliki nilai signifikansi yang lebih kecil dari $\mathrm{a}=5 \%$. Variabel-variabel tersebut adalah variabel pengetahuan (sig. $=0,003)$, sikap $($ sig. $=0,018)$ dan variabel dukungan tenaga kesehatan (sig. = 0,030). Variabel yang paling signifikan mempengaruhi perilaku donor darah adalah variable pengetahuan dengan nilai $\operatorname{Exp}$ (B) terbesar yaitu 39,565.

Besarnya pengaruh ditunjukkan dengan nilai EXP (B). Besar EXP (B) dalam penelitian ini adalah sebagai berikut:

1. Variabel pengetahuan memiliki nilai signifikan sebesar $0,003<0,05$, maka $\mathrm{Ha}$ diterima, sehingga ada pengaruh pengetahuan terhadap perilaku ibu dalam pemberian imunisasi dasar. Variabel pengetahuan memiliki nilai EXP (B) sebesar 39,565 , maka responden yang memiliki pengetahuan baik memiliki kecenderungan berperilaku baik dalam pemberian imunisasi dasar sebesar 39,565. Nilai B atau logaritma natural dari 390,565 adalah 3,678. Oleh karena nilai B bernilai positif, maka variabel pengetahuan memiliki hubungan positif dengan perilaku ibu dalam pemberian imunisasi dasar atau jika responden memiliki pengetahuan baik maka cenderung memberikan imunisasi dasar.

2. Variabel sikap memiliki nilai signifikan sebesar $0,018<0,05$, maka Ha diterima, sehingga ada pengaruh sikap terhadap terhadap perilaku ibu dalam pemberian imunisasi dasar. Variabel sikap memiliki nilai EXP (B) sebesar 12,865, maka responden yang memiliki sikap positif memiliki kecenderungan berperilaku baik dalam pemberian imunisasi dasar sebesar 12,865. Nilai B atau logaritma natural dari 12,865 adalah 2,554 . Oleh karena nilai B bernilai positif, maka variabel sikap memiliki hubungan positif dengan perilaku ibu dalam pemberian imunisasi dasar atau jika responden memiliki sikap positif maka cenderung memberikan imunisasi dasar.

3. Variabel dukungan tenaga kesehatan memiliki nilai signifikan sebesar $0,030<$ 0,05, maka Ha diterima, sehingga ada pengaruh dukungan tenaga kesehatan terhadap terhadap perilaku ibu dalam pemberian imunisasi dasar. Variabel dukungan tenaga kesehatan memiliki nilai EXP (B) sebesar 14,965, maka responden yang memiliki dukungan dari tenaga kesehatan memiliki kecenderungan berperilaku baik dalam pemberian imunisasi dasar sebesar 14,965 . Nilai B atau logaritma natural dari 14,965 adalah 2,706. Oleh karena nilai B bernilai positif, maka variabel dukungan tenaga kesehatan memiliki hubungan positif dengan perilaku ibu dalam pemberian imunisasi dasar atau jika responden mendapat dukungan dari tenaga kesehatan maka cenderung memberikan imunisasi dasar..

Dari perhitungan persamaan regresi logistik diatas diketahui nilai probabilitas atau 
predicted dalam penelitian ini adalah sebesar 0,969056 . Artinya bahwa secara bersama-sama variabel pengetahuan, sikap dan dukungan tenaga kesehatan berpengaruh atau memberikan kontribusi terhadap perilaku ibu dalam pemberian imunisasi dasar sebesar 0,969056 atau
$96,9 \%$.

Tabel 4. Hasil Uji Analisis Multivariat Uji Regresi Logistik Tahap II

\begin{tabular}{clcccccc}
\hline No & \multicolumn{1}{c}{ Variabel } & B & S.E & Wald & df & Sig & Exp (B) \\
\hline 1 & Pengetahuan & 3.678 & 1.219 & 9.106 & 1 & .003 & 39.565 \\
2 & Sikap & 2.554 & 1.079 & 5.609 & 1 & .018 & 12.865 \\
3 & Dukungan Nakes & 2.706 & 1.247 & 4.707 & 1 & .030 & 14.965 \\
\hline & Constant & -12.380 & 3.505 & 12.472 & 1 & .000 & .000 \\
\hline
\end{tabular}

\section{PEMBAHASAN}

Pengaruh Umur terhadap Perilaku Ibu dalam Pemberian Imunisasi Dasar. Hasil uji chi square menunjukkan bahwa tidak ada hubungan yang signifikan antara umur dengan perilaku ibu dalam pemberian imunisasi dasar di wilayah kerja Puskesmas Kosik Putih Kabupaten Padang Lawas Utara Tahun 2019 dengan nilai $p=0,525<0,05$. Hal ini ditunjukkan dari 59 jumlah responden, 43 responden yang berumur $<30$ tahun sebanyak $34,9 \%$ perilaku dalam pemberian imunisasi dasar kurang dan ada $65,1 \%$ yang baik. Sedangkan ibu yang berumur $\geq 30$ tahun yang sudah seharusnya sudah matang menjadi seorang ibu ada $68,8 \%$ perilaku dalam pemberian imunisasi dasar yang baik dan ada $31,3 \%$ yang masih kurang. Hal ini dapat diartikan bahwa tidak ada perbedaan antara tingkat usia ibu yang muda dan tua dalam mengimunisasikan bayinya.

Penelitian Rizani (2009), juga menyatakan tidak terdapat hubungan yang signifikan antara usia ibu dengan perilaku ibu dalam pemberian imunisasi. Sehingga usia dapat dikatakan bukan merupakan faktor risiko dalam pemberian imunisasi dasar bayi. Hal yang sama juga dikemujkakan oleh Helmiati (2011) yang dalam penelitiannya di Puskesmas Pasar Kuok juga menyatakan bahwa umur ibu tidak berpengaruh terhadap pemberian imunisasi hepatitis pada bayi 0-7 hari.

Menurut peneliti, usia bukan merupakan faktor resiko untuk mendapatkan pelayanan kesehatan terutama untuk imunisasi bayi, karena sama-sama mempunyai kesempatan untuk mengimunisasikan anaknya. Keikutsertaan pada pelayanan imunisasi tidak membedakan usia, baik ibu yang berusia kurang dari 30 tahun sampai yang berusia lebih dari 30 tahun tidak memliki perbedaan dalam berperan aktif pada program imunisasi.

Pengaruh Pendidikan terhadap Perilaku Ibu dalam Pemberian Imunisasi Dasar. Hasil uji chi square menunjukkan bahwa tidak ada hubungan yang signifikan antara pendidikan dengan perilaku ibu dalam pemberian imunisasi dasar di wilayah kerja Puskesmas Kosik Putih Kabupaten Padang Lawas Utara Tahun 2019 dengan nilai $p=0,232<0,05$. Hal ini ditunjukkan dari 59 jumlah responden, 30 responden yang berpendidikan rendah sebanyak $40,0 \%$ perilaku dalam pemberian imunisasi dasar kurang dan hanya 60,0 \% yang baik.

Tingkat pendidikan dan pengetahuan ibu sangat mempengaruhi terlaksananya kegiatan pelaksanaan imunisasi anak/bayi, baik itu pendidikan formal maupun non formal. Hal ini terjadi karena rata-rata ibu bayi sudah mendapatkan pendidikan rendah, yaitu sebanyak 50,8\% ibu memiliki pendidikan kategori rendah, sedangkan hanya 49,2\% ibu yang memiliki pendidikan kategori tinggi. Bayi yang mendapatkan imunisasi dasar lengkap ataupun tidak lengkap sama-sama mempunyai ibu yang memiliki pendidikan tinggi suatu ide baru dibandingkan ibu yang berpendidikan rendah sehingga informasi lebih mudah dapat diterima dan dilaksanakan (Ambarwati, 2013).

Hasil penelitian ini sejalan dengan penelitian Triana (2015) yang menyatakan bahwa tidak terdapat hubungan yang bermakna antara tingkat pendidikan orang tua dengan pemberian imunisasi dasar pada bayi di Kecamatan Kuranji Kota Padang tahun 2015 dengan nilai $p$-value sebesar 0,34 ( $p$-value > $0,05)$. 
Menurut peneliti ibu yang mempunyai tingkat pendidikan lanjut diperkirakan lebih mudah dalam menerima dan mengerti tentang pesan-pesan imunisasi yang disampaikan oleh petugas kesehatan, baik melalui penyuluhan maupun media massa, sehingga diharapkan dapat menerapkan informasi yang diterimanya, yaitu memberikan imunisasi lengkap kepada anaknya.

Pengaruh Pekerjaan terhadap Perilaku Ibu dalam Pemberian Imunisasi Dasar. Hasil uji chi square menunjukkan bahwa tidak ada hubungan yang signifikan antara pekerjaan dengan perilaku ibu dalam pemberian imunisasi dasar di wilayah kerja Puskesmas Kosik Putih Kabupaten Padang Lawas Utara Tahun 2019 dengan nilai $p=0,232>0,05$. Hal ini ditunjukkan dari 59 jumlah responden, 30 responden yang tidak bekerja sebanyak $40,0 \%$ perilaku dalam pemberian imunisasi dasar kurang dan ada $60,0 \%$ yang baik.

Status pekerjaan menjadi faktor risiko karena pada umumnya ibu yang bekerja memiliki waktu lebih sedikit untuk bersama dengan anak-anaknya. Hal ini dikarenakan meraka bekerja untuk memenuhi kebutuhan hidup sehari-hari, bahkan ada yang kedua orang tuanya juga ikut bekerja, sehingga terkadang kesehatan anak tidak diperhatikan.

Hasil penelitian ini sejalan dengan penelitian Triana (2015) yang menyatakan bahwa tidak terdapat hubungan yang bermakna antara pekerjaan orang tua dengan pemberian imunisasi dasar pada bayi di Kecamatan Kuranji Kota Padang tahun 2015 dengan nilai $p$-value sebesar 0,66 (p-value >0,05 hal ini juga menunjukkan bahwa tidak terdapat hubungan yang bermakna antara pekerjaan orang tua dengan pemberian imunisasi dasar lengkap pada bayi di Kecamatan Kuranji Kota Padang tahun 2015.

Menurut peneliti, orang tua/ibu yang tidak bekerja memiliki banyak waktu dirumah sehingga tidak ada alasan bagi mereka untuk tidak mengantarkan bayinya ke tempat pelayanan kesehatan agar diberikan imunisasi, tetapi anggapan awal dari peneliti yang menyatakan adanya hubungan yang bermakna antara pekerjaan orang tua/ ibu dengan pemberian imunisasi dasar lengkap pada bayi tidak terbukti.

Pengaruh Pengetahuan terhadap Perilaku Ibu dalam Pemberian Imunisasi Dasar. Hasil uji chi square menunjukkan bahwa ada hubungan yang signifikan antara pengetahuan dengan perilaku ibu dalam pemberian imunisasi dasar di wilayah kerja Puskesmas Kosik Putih Kabupaten Padang Lawas Utara Tahun 2019 dengan nilai $p=0,000<0,05$. Hal ini ditunjukkan dari 59 jumlah responden, 30 responden yang memiliki pengetahuan baik sebanyak $91,7 \%$ perilaku dalam pemberian imunisasi dasar baik dan hanya 8,3 \% yang kurang. Hasil analisis multivariat dengan regresi logistik diketahui nilai sig. 0,003 $<0,05$, dapat dikatakan ada pengaruh yang signifikan pengetahuan terhadap perilaku ibu dalam pemberian imunisasi dasar di wilayah kerja Puskesmas Kosik Putih Kabupaten Padang Lawas Utara Tahun 2019.

Pengetahuan ibu adalah sebagai salah satu faktor yang mempermudah (predisposing factor) terhadap terjadinya perubahan perilaku khususnya mengimunisasikan anak. Hal ini sesuai dengan pendapatan L.Green dalam buku Soekidjo Notoatmodjo yang menyatakan bahwa salah satu factor penentu terjadinya perubahan perilaku adalah adanya faktor pemudah (predisposing factor) yang di dalamnya termasuk tingkat pengetahuan.

Penelitian Rogers mengungkapkan bahwa perubahan perilaku tidak selalu melewati tahap-tahap. Apabila penerima perilaku baru atau adopsi perilaku melalui proses seperti ini didasari oleh pengetahuan, kesadaran, dan sikap yang positif, maka perilaku tersebut akan bertahan lama (long lasting). Sebaliknya, apabila perilaku itu tidak didasari oleh pengetahuan dan kesadaran maka tidak akan berlangsung lama. Perilaku yang didasari pengetahuan umumnya bersifat langgeng. Menurut Rogers, adopsi perilaku tidak selalu melewati tahap AIETA (Awarwness, Interest, Evaluation, Trial, Adoption) sehingga umumnya perilaku baru tersebut tidak langgeng. Sebaliknya, perilaku yang melalui proses AIETA (Awarwness, Interest, Evaluation, Trial, Adoption) akan bersifat langgeng (Kemenkes RI, 2014). 
Hasil penelitian ini sesuai dengan penelitian sebelumnya yang dilakukan oleh Dewi Setyani (2008) yang menyatakan bahwa ada hubungan antara pengetahuan ibu dengan kelengkapan imunisasi balita di Desa Nyatnyono Kecamatan Ungaran Barat Kabupaten Semarang, dengan $p=0,001$ ( $p<$ 0,05) (Elly, 2011).

Menurut peneliti, orang yang memiliki pengetahuan tentang sesuatu hal maka orang tersebut akan mengaplikasikan pengetahuannya tersebut dalam kehidupannya sehari-hari, begitu juga dengan masalah imunisasi, orang tua/ ibu dengan pengetahuan tinggi tentang imunisasi maka mereka akan memberikan imunisasi dasar yang lengkap pada banyinya serta memperhatikan kapan waktu yang tepat untuk memberikan imunisasi tersebut. Begitu juga sebaliknya ibu yang memiliki pengetahuan rendah maka mereka tidak akan mengetahui apa yang seharusnya dilakuan pada bayinya terutama masalah imunisasi.

Pengaruh Sikap terhadap Perilaku Ibu dalam Pemberian Imunisasi Dasar. Hasil uji chi square menunjukkan bahwa ada hubungan yang signifikan antara sikap dengan perilaku ibu dalam pemberian imunisasi dasar di wilayah kerja Puskesmas Kosik Putih Kabupaten Padang Lawas Utara Tahun 2019 dengan nilai $p$ $=0,000<0,05$. Hal ini dapat dilihat dari 59 jumlah responden, 33 responden yang memiliki sikap yang positif sebanyak $93,9 \%$ perilaku dalam pemberian imunisasi dasar baik dan hanya $6,1 \%$ yang kurang. Hasil analisis multivariat dengan regresi logistik diketahui nilai sig. $0,018<0,05$, dapat dikatakan ada pengaruh yang signifikan sikap terhadap perilaku ibu dalam pemberian imunisasi dasar di wilayah kerja Puskesmas Kosik Putih Kabupaten Padang Lawas Utara Tahun 2019.

Menurut Thomas \& Znanicki dalam Wawan (2010), sikap adalah predisposisi untuk melakukan atau tidak melakukan suatu perilaku tertentu, sehingga sikap bukan hanya kondisi internal psikologis yang murni dari individu, tetapi lebih merupakan proses kesadaran yang bersifat individual dalam arti proses ini terjadi secara subjektif dan unik pada diri seseorang.
Fenomena sikap adalah mekanisme mental yang mengevaluasi, membentuk pandangan, mewarnai perasaan, dan akan ikut menentukan kecenderungan perilaku kita terhadap manusia atau sesuatu yang kita hadapi, bahkan terhadap diri sendiri. Padangan dan perasaan kita terpengaruh oleh ingatan akan masa lalu, oleh apa yang kita ketahui dan kesan kita terhadap apa yang sedang kita hadapi saat ini (Hanifah, 2011).

Penelitian ini sejalan dengan penelitian yang dilakukan Oktaviani (2015) yang menyatakan bahwa sikap ibu berpengaruh terhadap penolakan ibu dalam pemberian imunisasi dasar lengkap. Selain itu sikap ibu juga berhubungan dengan penolakan pemberian imunisasi dasar lengkap. Penelitian ini juga didukung oleh Dwiastuti dan Prayitno (2013) bahwa sikap ibu memiliki hubungan yang bermakna dengan pemberian imunisasi (Dwiastuti, 2013).

Menurut peneliti, Sikap responden dalam penelitian ini meliputi kenyamanan ibu saat anak diimunisasi, kenyamanan ibu setelah anak diimunisasi, sikap ibu tentang efek dari imunisasi, padangan agama (halal/haram) pemberian imunisasi. Faktor yang mempengaruhi banyaknya responden yang memiliki sikap positif tentang imunisasi adalah pengetahuan yang baik tentang imunisasi, semakin baik pengetahuan ibu tentang imunisasi maka akan memberikan kontribusi yang besar terhadap pembentukan sikap yang baik/positif tentang imunisasi. Seseorang yang telah mengetahui kebenaran akan suatu hal maka mereka juga akan memiliki sikap yang positif terhadap hal tersebut, begitu juga dengan imunisasi. Pembentukan sikap ini juga tidak terlepas dari orang lain yang dianggap penting, media massa, faktor emosional dari individu serta pengalamam tentang imunisasi.

Pengaruh Sosial Budaya terhadap Perilaku Ibu dalam Pemberian Imunisasi Dasar. Hasil uji chi square menunjukkan bahwa ada hubungan yang signifikan antara sosial budaya dengan perilaku ibu dalam pemberian imunisasi dasar di di wilayah kerja Puskesmas Kosik Putih Kabupaten Padang Lawas Utara Tahun 2019 dengan nilai $p=0,006<0,05$. Hal ini dapat dilihat dari 59 jumlah responden, 38 
responden yang memiliki sosial budaya yang baik sebanyak $78,9 \%$ perilaku dalam pemberian imunisasi dasar baik dan hanya $21,1 \%$ yang kurang. Hasil analisis multivariat dengan regresi logistik diketahui nilai sig. 0,271 >0,05, dapat dikatakan tidak ada pengaruh yang signifikan sosial budaya terhadap perilaku ibu dalam pemberian imunisasi dasar di wilayah kerja Puskesmas Kosik Putih Kabupaten Padang Lawas Utara Tahun 2019.

Menurut Depkes (2009) salah satu penyebab rendahnya pencapaian imunisasi dikarena adanya faktor budaya. Hal ini akan mempengaruhi dalam pemberian imunisasi karena ada wilayah-wilayah tertentu di Indonesia yang mempunyai budaya yang berpengaruh pada pemberian imunisasi sehingga cakupan imunisasi masih belum bisa mencapai target. Penelitian ini sejalan dengan penelitian Rahmawati (2013) yang menyatakan bahwa tidak ada pengaruh antara kepercayaan terhadap ketidaklengkapan status imunisasi pada bayi atau balita. Penelitian Rahmawati ini memberikan gambaran bahwa kepercayaan.

Pengaruh Ketersediaan Fasillitas Kesehatan terhadap Perilaku Ibu dalam Pemberian Imunisasi Dasar. Hasil uji chi square menunjukkan bahwa ada hubungan yang signifikan ketersediaan fasilitas kesehatan dengan perilaku ibu dalam pemberian imunisasi dasar di wilayah kerja Puskesmas Kosik Putih Kabupaten Padang Lawas Utara Tahun 2019 dengan nilai $p=0,045<0,05$. Hal ini dapat dilihat dari 59 jumlah responden, 34 responden yang menyatakan ketersediaan fasilitas kesehatan baik sebanyak $76,5 \%$ perilaku dalam pemberian imunisasi dasar baik dan hanya $23,5 \%$ yang kurang. Hasil analisis multivariat dengan regresi logistik diketahui nilai sig. 0,376 $>0,05$, dapat dikatakan tidak ada pengaruh yang signifikan ketersediaan fasilitas kesehatan terhadap perilaku ibu dalam pemberian imunisasi dasar di wilayah kerja Puskesmas Kosik Putih Kabupaten Padang Lawas Utara Tahun 2019.

Menurut Notoatmodjo, ketersediaan sarana dan prasarana atau fasilitas pelayanan kesehatan bagi masyarakat seperti puskesmas, rumah sakit, poli klinik, posyandu, polindes, praktek dokter, praktek bidan desa, dan lain - lain akan mendukung atau memungkinkan terwujudnya perilaku kesehatan seperti perilaku ibu dalam mengimunisasikan bayinya. Hasil penelitian ini sejalan dengan peneltian yang dilakukan Hafid (2016), menunjukkan bahwa tidak ada pengaruh yang signifikan antara ketersediaan sarana pelayanan kesehatan terhadap kelengkapan imunisasi dasar pada bayi dengan nilai $\mathrm{p}=0,583$.

Pengaruh Keterjangkauan Fasillitas Kesehatan terhadap Perilaku Ibu dalam Pemberian Imunisasi Dasar. Hasil uji chi square menunjukkan bahwa ada hubungan yang signifikan keterjangkauan fasilitas kesehatan dengan perilaku ibu dalam pemberian imunisasi dasar di wilayah kerja Puskesmas Kosik Putih Kabupaten Padang Lawas Utara Tahun 2019 dengan nilai $p=0,037<0,05$. Hal ini dapat dilihat dari 59 jumlah responden, 40 responden yang menyatakan keterjangkauan fasilitas kesehatan terjangkau sebanyak $75,0 \%$ perilaku dalam pemberian imunisasi dasar baik dan hanya $25,0 \%$ yang kurang. Hasil analisis multivariat dengan regresi logistik diketahui nilai sig. 0,472 >0,05, dapat dikatakan tidak ada pengaruh yang signifikan keterjangkauan fasilitas kesehatan terhadap perilaku ibu dalam pemberian imunisasi dasar di wilayah kerja Puskesmas Kosik Putih Kabupaten Padang Lawas Utara Tahun 2019.

Akses terhadap pelayanan berarti bahwa pelayanan kesehatan tidak terhalang oleh keadaan geografis, sosial, ekonomi, budaya, organisasi atau hambatan jasa. Akses geografis dapat diukur dengan jenis transportasi, jarak, waktu perjalanan dan hambatan fisik lain yang dapat menghalangi seseorang untuk memperoleh pelayanan kesehatan. Menurut Black (1980) dalam Tamin (2000); aksesibilitas adalah suatu ukuran kenyamanan atau kemudahan mengenai cara lokasi tata guna lahan berinteraksi satu sama lain dan mudah atau susahnya lokasi tersebut dicapai melalui sistem jaringan transportasi.

Menurut peneliti, jarak yang semakin jauh maka semakin lama waktu tempuhnya dan semakin mahal biaya angkutannya, tentunya dengan sarana untuk menempuh jarak yang sama, penduduk yang tinggal di desa terpencil dengan tidak didukung oleh kemudahan 
transportasi, waktu tempuh yang lebih lama dan biaya angkutan semakin mahal sehingga hal ini akan memberikan pertimbangan tersendiri bagi masyarakat untuk berperilaku hibup bersih dan sehat terutama pada kesehatan keluarga.

Pengaruh Dukungan Tenaga Kesehatan terhadap Perilaku Ibu dalam Pemberian Imunisasi Dasar. Hasil uji chi square menunjukkan bahwa ada hubungan yang signifikan dukungan tenaga kesehatan dengan perilaku ibu dalam pemberian imunisasi dasar di wilayah kerja Puskesmas Kosik Putih Kabupaten Padang Lawas Utara Tahun 2019 dengan nilai $p=0,000<0,05$. Hal ini dapat dilihat dari 59 jumlah responden, 30 responden yang menyatakan mendapat dukungan tenaga kesehatan sebanyak $90,0 \%$ perilaku dalam pemberian imunisasi dasar baik dan hanya $10,0 \%$ yang kurang. Hasil analisis multivariat dengan regresi logistik diketahui nilai sig. 0,030 $<0,05$, dapat dikatakan ada pengaruh yang signifikan dukungan tenaga kesehatan terhadap perilaku ibu dalam pemberian imunisasi dasar di wilayah kerja Puskesmas Kosik Putih Kabupaten Padang Lawas Utara Tahun 2019.

Seorang petugas kesehatan mempunyai peran sebagai seorang pendidik, peran ini dilakukan dengan membantu klien dan keluarga dalam meningkatkan tingkat pengetahuan kesehatan, gejala penyakit bahkan tindakan yang diberikan, sehingga terjadi perubahan perilaku klien dan keluarga setelah dilakukan pendidikan kesehatan selain itu juga petugas kesehatan merupakan tempat konsultasi terhadap masalah atau perilaku kesehatan yang di dapat. Peran petugas kesehatan dalam program imunisasi meliputi penyusunan, perencanaan, pelaksanaan imunisasi, pengelolaan, rantai vaksin, penanganan limbah, standar tenaga dan pelatihan teknis, pencatatan dan pelaporan, supervise, dan bimbingan teknis, serta monitoring dan evaluasi (Senewe, 2017).

Pengaruh Dukungan Suami/ Keluarga terhadap Perilaku Ibu dalam Pemberian Imunisasi Dasar. Hasil uji chi square menunjukkan bahwa ada hubungan yang signifikan dukungan suami/ keluarga dengan perilaku ibu dalam pemberian imunisasi dasar di wilayah kerja Puskesmas Kosik Putih Kabupaten Padang Lawas Utara Tahun 2019 dengan nilai $p=0,000<0,05$. Hal ini dapat dilihat dari 59 jumlah responden, 30 responden yang menyatakan mendapat dukungan suami/ keluarga sebanyak $80,0 \%$ perilaku dalam pemberian imunisasi dasar baik dan hanya $20,0 \%$ yang kurang. Hasil analisis multivariat dengan regresi logistik diketahui nilai sig. 0,725 $>0,05$, dapat dikatakan tidak ada pengaruh yang signifikan dukungan suami/ keluarga terhadap perilaku ibu dalam pemberian imunisasi dasar di wilayah kerja Puskesmas Kosik Putih Kabupaten Padang Lawas Utara Tahun 2019.

Penelitian Istriyati (2011) menyatakan bahwa untuk mewujudkan sikap menjadi suatu perbuatan yang nyata diperlukan faktor pendukung atau suatu kondisi yang memungkinkan, antara lain adalah fasilitas. Sikap ibu yang positif terhadap imunisasi harus mendapat konP rmasi dari suaminya dan ada fasilitas imunisasi yang mudah dicapai, agar ibu tersebut mengimunisasikan anaknya. Disamping faktor fasilitas, juga diperlukan dukungan dari pihak lain misalnya suami, orang tua, mertua, dan saudara.

\section{KESIMPULAN}

Berdasarkan penelitian yang telah dilakukan maka dapat disimpulkan bahwa tidak ada pengaruh umur, pendidikan, pekerjaan, sosial budaya, ketersediaan fasilitas kesehatan, keterjangkauan fasilitas kesehatan dan dukungan suami/ keluarga dengan perilaku ibu dalam pemberian imunisasi dasar. Ada pengaruh pengetahuan, sikap dan dukungan tenaga kesehatan dengan perilaku ibu dalam pemberian imunisasi dasar. Variabel yang paling berpengaruh terhadap perilaku ibu dalam pemberian imunisasi dasar adalah pengetahuan dengan nilai Exp (B) sebesar 39,565 sehingga dapat dikatakan variabel pengetahuan memiliki nilai paling tinggi dibandingkan variabel sikap dan dukungan tenaga kesehatan.

\section{SARAN}

Adapun saran yang dapat penulis sampaikan terkait dengan hasil penelitian ini adalah agar Dinas Kesehatan Padang Lawas Utara lebih meningkatkan cakupan imunisasi dasar di Kabupaten Padang Lawas Utara 
khususnya wilayah kerja Puskesmas Kosik Putih dengan membuat kebijakan bagi setiap petugas kesehatan wajib memberikan imunisasi dasar dan dapat membuat perencanaan kebutuhan dan distribusi vaksin ke petugas kesehatan yang bertugas dalam pemberian imunisasi dasar, serta penyediaan cool pack untuk tempat vaksin di desa dan bagi petugas puskesmas khususnya bidan agar dapat secara aktif melakukan penyuluhan pada setiap ibu yang melahirkan dan bayi yang belum mendapatkan imunisasi dasar serta membuat pencataan dan pelaporan imunisasi dengan baik dan sejalan dengan laporan kunjungan neonatal.

\section{REFERENSI}

Ambarwati ER. (2013). Pendidikan, pendapatan kepala keluarga dengan perilaku hidup bersih dan sehat. Ilmu Kebidanan. 2013;1(1):45-51.

Departemen Kesehatan RI. (2009). UndangUndang Republik Indonesia Nomor 36. Tahun 2009 tentang kesehatan. Jakarta: Kementrian Kesehatan RI.

Dinas Kesehatan Kabupaten Padang Lawas Utara. (2017). Profil Kesehatan Kabupaten Padang Lawas Utara.

Dinas Kesehatan Provinsi Sumatera Utara. (2016). Profil Kesehatan Provinsi Sumatera Utara.

Dwiastuti P. (2013). Faktor-faktor yang berhubungan dengan pemberian Imunisasi BCG di wilayah kerja puskesmas upt cimanggis kota depak. Jurnal Ilmiah Kesehatan ;Volume $5(1): 36-41$.

Elly, I. (2011). Faktor-Faktor Yang Berhubungan Dengan Kelengkapan Imunisasi Dasar Pada Bayi Di Desa Kumpulrejo Kecamatan Argomulyo Kota Salatiga. 2011.

Hafid, W. (2016). Faktor determinan status imunisasi dasar lengkap pada bayi di puskesmas konang dan geger. Jurnal Wiyata, Vol. 3 No. 1 Tahun 2016

Hanifah E. (2011). Cara Hidup Sehat. Jakarta: Sarana Bangun Pustaka.

Helmiati, (2011). Faktor-faktor yang berhubungan dengan pemberian iminisasi hepatitis b-0 (0-7 hari) pada bayi (0-11 bulan) di puskesmass pasar kuok kabupaten pesisir selatan tahun 2011. Skripsi Depok FKM-UI

Ikatan Dokter Anak Indonesia. (2014). Panduan imunisasi anak. Jakarta: Badan Penerbit IDAI; 2014.

Istriyati, Elly. 2011. Faktor-faktor yang berhubungan dengan kelengkapan imunisasi dasar pada bayi di desa kumpulrejo kecamatan argomulyo kota salatiga. Skripsi FKM Semarang: Universitas Negeri Semarang.

Kemenkes R.I. (2014). Rancangan Teknokratik Renstra Kementrian Kesehatan 20152019.

Kemenkes RI. (2015). Profil Kesehatan Indonesia tahun 2015.

Kemenkes RI. (2016). Profil Kesehatan Indonesia tahun 2016

Lisnawati. 2011. Generasi sehat melalui imunisasi. Jakarta: Trans Info Media.

Octaviani, U. (2015). Hubungan keaktifan keluarga dalam kegiatan posyandu dengan status gizi balita di desa rancaekek kulon kecamatan rancaekek. Fakultas Ilmu Keperawatan Universitas Padjajaran, Bandung.

Rizani, A., Hakimi, M., Ismail, D. (2009). Hubungan pengetahuan, sikap dan perilaku ibu dalam pemberian imunisasi hepatitis b 0-7 hari di kota banjarmasin. Jurnal Berita Kedokteran Masyarakat. Volume 25, Nomor 1, Maret 2009.

Rahmawati AI. (2013). Faktor yang mempengaruhi kelengkapan imunisasi dasar di kelurahan krembangan utara. FKM Unair. 2013.

Senewe, M. et al. (2017). Analisis FaktorFaktor Yang Berhubungan Dengan Kepatuhan Ibu Dalam Pemberian Imunisasi Dasar Di Puskesmas Tongkaina Kecamatan Bunaken Kota Madya Manado

Tamin, Ofyar, Z. (2000). Perencanaan dan permodelan transportasi. bandung. Indonesia: Penerbit ITB

Triana, Vivi. (2015). Faktor Yang BerhubunganDengan Pemberian ImunisasiDasar Lengkap Pada Bayi Tahun 2015 
Wawan,A dkk. (2010), Teori \& pengukuran pengetahuan, sikap, dan perilaku manusia. Yogyakarta : Nuha Medika

World Health Organizatio. (2014). About cardiovascular diseases. World Health Organization. Geneva. Cited July 15th 2014.

World Health Organization. (2016). World Health Statistic 2016 Monotoring Health For The SDGs.:54 